\title{
H. PETERMANN
}

\section{REISEN IM ORIENT.}

ERSTER BAND. 


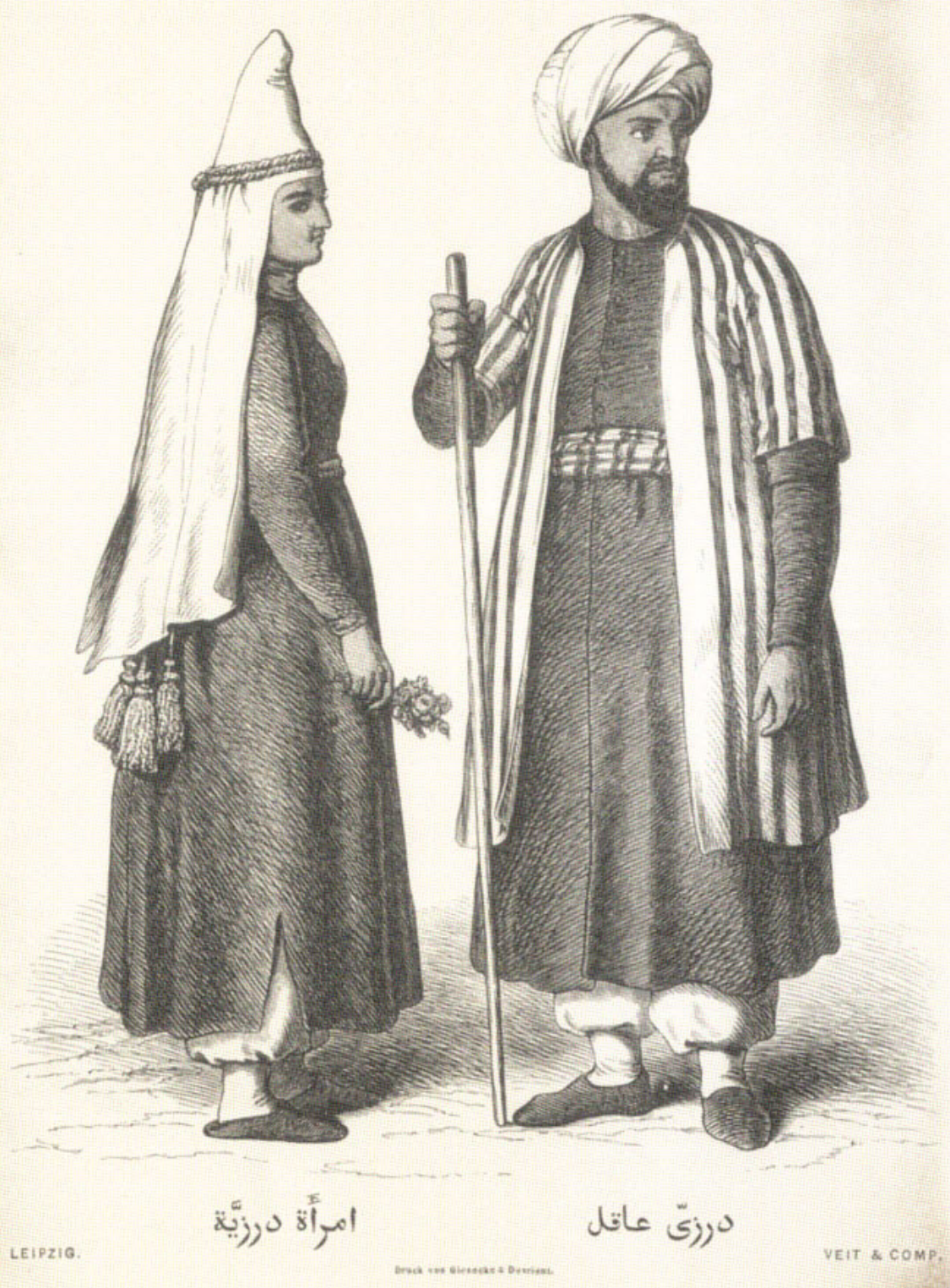




\section{REISEN IM ORIENT \\ voN}

\section{H. PETERMANN.}

ERSTER BAND.

MIT EINEM TITELBILD.

LEIPZIG

VERLAG VON VEIT \& COMP.

1860. 
LEIPZIG

DRUCK VON GIESECKE \& DEVRIFNT. 